\title{
PENGARUH ANTARA TINGKAT SUKU BUNGA, TINGKAT INFLASI, DAN JUMLAH BARANG IMPOR DENGAN NILAI TUKAR RUPIAH TERHADAP DOLAR AMERIKA
}

\author{
Oleh: \\ Wulan Anggraeni ${ }^{1}$ \\ Indra Suyahya ${ }^{2}$ \\ Dosen Program Studi Pendidikan Matematika \\ Fakultas Teknik dan Ilmu Pengetahuan Alam ${ }^{1}$ \\ Dosen Program Studi Pendidikan Ekonomi \\ Fakulas Ilmu Pendidikan dan Pengetahuan Sosial ${ }^{2}$ \\ Universitas Indraprasta PGRI \\ Email: \\ wulangussetiyo@gmail.com ${ }^{1}$ \\ Indrasuyahya@gmail.com ${ }^{2}$
}

\begin{abstract}
ABSTRAK
Tujuan dari penelitian ini adalah untuk mengetahui apakah terdapat pengaruh antara tingkat suku bunga, tingkat inflasi dan jumlah barang impor dengan nilai tukar rupiah terhadap dolar amerika. Sumber data diperoleh dari www.bps.go.id dan www.BI.go.id. data yang diperoleh merupakan data deret waktu pada periode januari 2011 sampai dengan Oktober 2015. Uji hipotesis yang dipergunakan menggunakan statistika nonparametrik dikarenakan data dari tingkat suku bunga, tingkat inflasi dan nilai tukar rupiah terhadap dolar Amerika tidak berdistribusi normal. Uji hipotesis yang dilakukan adalah uji korelasi parsial menggunakan uji kendal tau dan uji regresi sederhana menggunakan uji theil. Berdasarkan uji hipotesis yang diperoleh bahwa secara parsial tingkat suku bunga, tingkat inflasi, dan jumlah barang impor memiliki hubungan dan pengaruh terhadap nilai tukar rupiah terhadap dolar Amerika.

Kata Kunci: Tingkat Suku Bunga, Tingkat Inflasi, Jumlah Barang Impor, Nilai Tukar Rupiah terhadap Dolar Amerika.
\end{abstract}

\section{A. PENDAHULUAN}

Nilai tukar atau dikenal dengan kursa dalah sebuah perjanjian yang dikenal sebagai nilaitukar matauang terhadap pembayaran saat kini atau dikemudian hari, antara dua mata uang masing-masing negara atau wilayah. Pada tanggal 14 agustus 1998, Pemerintah Indonesia menetapkan sistem kurs mengambang bebas, artinya kurs dibiarkan berfluktuasi dengan bebas untuk menanggapi kondisi perekonomian yang sedang berubah. Hal ini menyebabkan depresiasi nilai tukar rupiah terhadap dolar Amerika menjadi sangat besar.

Banyak faktor yang mempengaruhi pergerakan nilai tukar rupiah terhadap dolar. Di dalam bukunya Sukirno (2014) menyatakan bahwa faktor-faktor yang mempengaruhi nilai tukar rupiah adalah perubahan dalam cita rasa masyarakat, 
perubahan harga barang ekspor dan impor, kenaikan harga inflasi, perubahan suku bunga dan tingkat pengembalian investasi, dan yang terakhir adalah pertumbuhan ekonomi.

Faktor pertama adalah perubahan cita rasa masyarakat. Perubahan citarasa masyarakat mendorong corak konsumsi masyarakat itu sendiri, ketika produk dalam negeri memiliki kualitas bagus, akan mendorong masyarakat untuk menggunakan produk dalam negeri, sehingga menyebabkan keinginan mengimpor berkurang. Dan berlaku sebaliknya. Selain kualitas barang impor dan ekspor, harga mempengaruhi jumlah barang yang akan diekspor atau diimpor. Jika barang dalam negeri memiliki harga murah, hal ini akan mendorong suatu negara untuk mengekspor barang ke luar negeri, dan begitu juga sebaliknya. Hal ini pun berlaku untuk permintaan barang impor, pengurangan harga impor akan mengurangi impor,hal ini akan menyebabkan perubahan dalam penawaran dan permintaan ke atas mata uang suatu negara.

Faktor kedua adalah inflasi. Inflasi sangat besar pengaruhnya kepada nilai tukar rupiah. inflasi menyebabkan harga di dalam negeri lebih mahal dari harga luar negeri dan oleh sebab itu inflasi menambah kecenderungan suatu negara untuk mengimpor, harga barang-barang ekspor pun akan cenderung mahal, selanjutnya inflasi akan menyebabkan permintaan valuta asing akan bertambah artinya harga mata uang negara yang mengalami inflasi merosot.

Selain dua hal di atas, selanjutnya adalah perubahan suku bunga dan tingkat pengembalian investasi. Perubahan suku bunga dan tingkat pengembalian investasi sangat penting peranannya dalam mempengaruhi aliran modal. Suku bunga dan tingkat pengembalian investasi yang rendah akan mengakibatkan arus modal mengalir ke luar negeri, dan sebaliknya. Jika aliran modal lebih banyak ke luar negeri, maka nilai mata uang negara tersebut akan merosot, dan sebaliknya pun akan terjadi.

Faktor yang terakhir adalah pertumbuhan ekonomi. Suatu negara dengan pertumbuhan ekonomi yang baik akan memiliki kecenderungan untuk mengekspor barang dibandingkan mengimpor barang. Seperti kita ketahui suatu negara yang lebih banyak mengimpor barang maka penawaran mata uang negara yang mengimpor akan naik.

Berdasarkan uraian di atas, maka akan dianalisis faktor apa saja yang mempengaruhi pergerakan nilai tukar rupiah terhadap dolar Amerika. Faktor yang akan diteliti adalah tingkat suku bunga, jumlah barang impor dan nilai tukar rupiah terhadap dolar Amerika. Oleh karena itu, judul dari penelitian ini adalah "Pengaruh inflasi, tingkat suku bunga, dan jumlah barang impor terhadap nilai tukar rupiah terhadap Dolar amerika".

\section{B. KAJIAN PUSTAKA Nilai tukar (kurs)}

Menurut Mankiw (2000) kurs dibedakan menjadi 2 yaitu, kurs nominal dan kurs riil. Kurs nominal adalah harga relatif dari mata uang dua negara. Sedangkan, kurs riil adalah harga relatif dari barang-barang kedua negara. Pada penelitian ini yang akan dibahas adalah kurs nominal. Selanjutnya Rahardja (2014) menyatakan nilai tukar adalah nilai yang menggambarkan berapa banyak suatu mata uang 
harus dipertukarkan untuk memperoleh satu unit mata uang lain. Sedangkan, menurut Sukirno (2014) kurs valuta asing atau kurs mata uang asing menunjukan harga atau nilai mata uang suatu negara dinyatakan dalam nilai mata uang negara lain.

Berdasarkan teori di atas dapat disimpulkan bahwa nilai tukar adalah harga atau nilai mata uang suatu negara yang menggambarkan berapa banyak suatu mata uang harus dipertukarkan untuk memperoleh satu unit mata uang lain.

Penentuan kurs yang digunakan dalam penelitian ini adalah kurs mengambang, kurs mengambang adalah kurs yang dibiarkan berfluktuasi dengan bebas untuk menanggapi kondisi perekonomian yang sedang berubah dalam Mankiw (2000).

\section{Tingkat Suku Bunga}

Mankiw (2000) menyatakan bahwa tingkat bunga dibagi menjadi dua, yaitu tingkat bunga nominal dan tingkat bunga riil. Tingkat bunga nominal adalah tingkat bunga yang dibayarkan oleh bank, dan tingkat bunga riil adalah kenaikan dalam daya

\section{Tingkat Inflasi}

Mankiw (2000) menyatakan bahwa inflasi adalah kenaikan harga barang yang terus menerus. Menurut Rahardja (2014), Inflasi adalah kenaikan harga barang-barang yang bersifat umum dan terus menerus. Dari definisi ini, ada tiga komponen yang harus dipenuhi agar dapat dikatakan inflasi yaitu kenaikan harga, bersifat umum, dan berlangsung terus menerus. Sedangkan menurut Sukirno (2015) Inflasi adalah kenaikan harga barang-barang yang terus menerus, inflasi dibedakan menjadi 3 yaitu inflasi tarikan permintaan, inflasi desakan biaya, dan inflasi impor.

Berdasarkan teori di atas maka dapat disimpulkan bahwa inflasi adalah kenaikan harga barang yang berlangsung terus menerus.

Tingkat inflasi menurut Mankiw (2000) adalah perubahan persentasi dalam tingkat harga beli anda.

\section{Jumlah Barang Impor}

Menurut kamus besar bahasa Indonesia (2007) Impor adalah pemasukan barang dan sebagainya dari luar negeri,sehingga jumlah barang impor adalah banyaknya pemasukan barang dan sebagainya dari luar negeri.

\section{METODE PENELITIAN}

Metode penelitian yang digunakan dalam penelitian ini adalah metode survei. Populasi terjangkau dalam penelitian ini adalah data deret waktu tingkat inflasi, tingkat suku bunga, jumlah barang impor dan nilai tukar rupiah. Sedangkan sampel dalam penelitian ini adalah data waktu tingkat inflasi, tingkat suku bunga, jumlah barang impor dan nilai tukar rupiah pada periode 2011 sampai dengan 2015.

Teknik pengumpulan data menggunakan purposive sampling. Data dalam penelitian ini adalah dokumentasi yang dilakukan untuk memperoleh data 
transaksi nilai tukar rupiah, tingkat inflasi, tingkat suku bunga dan jumlah barang impor yang dipublikasi oleh Bank Indonesia dan Biro Pusat Statsitik.

Teknik analisis yang akan digunakan dalam penelitian ini adalah korelasi ganda dan regresi ganda. Sebelum melakukan uji hipotesis menggunakan korelasi ganda, langkah awal adalah melakukan uji persyaratan data yaitu uji normalitas, uji multikolinearitas, uji heteroskedastisitas, uji linier. jika uji persyaratan data tidak terpenuhi, maka akan dianalisis menggunakan nonparametrik yaitu menganalisis hubungan setiap variabel secara parsial dan regresi sederhana.

\section{HASIL DAN PEMBAHASAN}

Berikut ini adalah deskripsi data dari setiap variabel

\section{Tingkat suku bunga}

Data tingkat suku bunga diperoleh dari data deret waktu periode Januari 2011 sampai dengan Oktober 2015, banyaknya data sebanyak 58 data.

\section{Tabel 1.}

\section{Deskripsi Tingkat suku bunga}

\begin{tabular}{|c|c|c|}
\hline \multicolumn{3}{|c|}{ Statistics } \\
\hline \multicolumn{3}{|c|}{ tingkat suku bunga } \\
\hline $\mathrm{N}$ & Valid & 58 \\
\hline & Missing & 0 \\
\hline & & 6,7478 \\
\hline & & 6,7500 \\
\hline Mo & & 7,50 \\
\hline & tion & ,76680 \\
\hline & & 5,75 \\
\hline & & 7,75 \\
\hline Sul & & 391,38 \\
\hline
\end{tabular}

Rata-rata tingkat suku bunga, median, dan modus secara berturut-turut adalah 6,75, 6,75 dan 7,5. Nilai terendah dari tingkat suku bunga adalah sebesar 5,75, nilai ini terjadi pada kurun waktu februari 2012 sampai dengan mei 2012. Nilai tertinggi dari tingkat suku bunga adalah sebesar 7,75 yang terjadi pada bulan januari 2015.

\section{Tingkat inflasi}

Data tingkat suku bunga diperoleh dari data deret waktu periode Januari 2011 sampai dengan Oktober 2015, banyaknya data sebanyak 58 data. 
Tabel 2. Deskripsi Data Inflasi

\begin{tabular}{|c|c|c|}
\hline \multicolumn{3}{|c|}{ Statistics } \\
\hline \multicolumn{3}{|c|}{ tingkat inflasi } \\
\hline $\mathrm{N}$ & $\begin{array}{l}\text { Valid } \\
\text { Missing }\end{array}$ & \\
\hline \multicolumn{2}{|c|}{ Mean } & 5,9698 \\
\hline \multicolumn{2}{|c|}{ Median } & 5,9400 \\
\hline \multicolumn{2}{|c|}{ Mode } & $4,53^{\mathrm{a}}$ \\
\hline \multicolumn{2}{|c|}{ Std. Deviation } & 1,53615 \\
\hline \multicolumn{2}{|c|}{ Minimum } & 3,56 \\
\hline \multicolumn{2}{|c|}{ Maximum } & 8,79 \\
\hline & & 346,25 \\
\hline \multicolumn{3}{|c|}{$\begin{array}{l}\text { a. Multiple modes exist. The smallest value } \\
\text { is shown }\end{array}$} \\
\hline
\end{tabular}

Rata-rata tingkat inflasi, median, dan modus secara berturut-turut adalah 5,97, $5,94,4,53$. Nilai minimum sebesar 3,56 yang terjadi pada bulan maret 2012, sedangkan nilai maksimum sebesar 8,79 yang terjadi pada bulan September 2013.

\section{Jumlah barang Impor}

Data jumlah barang impor diperoleh data deret waktu periode Januari 2011 sampai dengan Oktober 2015, banyaknya data sebanyak 58 data.

\section{Tabel 3.}

\section{Deskripsi data jumlah barang impor}

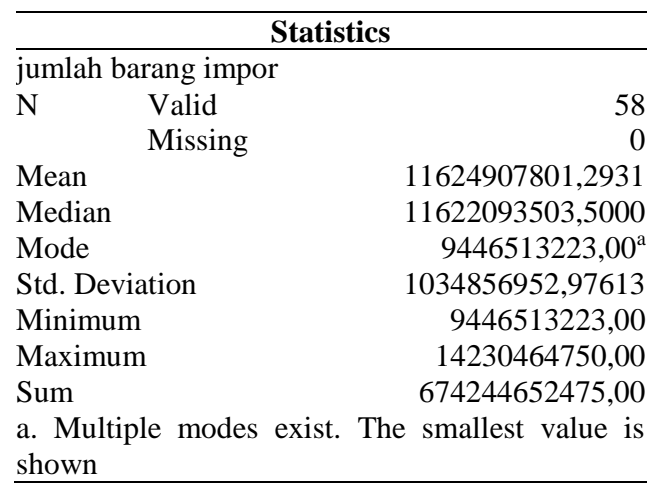

Rata-rata jumlah barang impor, median, dan modus secara berturut-turut adalah 11624907801,$29 ; 11622093503,5 ; 9446513223$. Nilai minimum sebanyak 9446513223 yang terjadi pada bulan Februari 2011, sedangkan nilai tertinggi sebanyak 14230464750 yang terjadi pada bulan Desember 2014.

\section{Nilai tukar rupiah terhadap dolar Amerika}

Data nilai tukar rupiah terhadap dolar Amerika diperoleh data deret waktu periode Januari 2011 sampai dengan Oktober 2015, banyaknya data sebanyak 58 data.

Rata-rata nilai tukar rupiah, median dan modus secara berturut-turut adalah 10670,35, 9821,5, 9687. Nilai minimum sebesar 8532 yang terjadi pada Agustus 2011, sedangan nilai tertinggi sebesar 14369 yang terjadi pada bulan September 2015. 
Tabel 4.

Deskripsi data nilai tukar rupiah terhadap dolar Amerika

\section{Uji Persyaratan Data}

\begin{tabular}{|c|c|c|}
\hline \multicolumn{3}{|c|}{ Statistics } \\
\hline \multicolumn{3}{|c|}{ nilai tukar rupiah terhadap dolar amerika } \\
\hline \multirow[t]{2}{*}{$\mathrm{N}$} & Valid & 58 \\
\hline & Missing & 0 \\
\hline & & 10670,3448 \\
\hline & & 9821,5000 \\
\hline & & 9687,00 \\
\hline & tion & 1693,81312 \\
\hline & & 8532,00 \\
\hline & & 14369,00 \\
\hline $\mathrm{Su}$ & & 618880,00 \\
\hline
\end{tabular}

Uji persyaratan data yang akan dilakukan adalah, uji normalitas, uji multikolinearitas, uji heterokedastisitas, dan uji normal baku. Uji normalisasi menggunakan uji kolmogorov smirnov.

Tabel 5.

Uji normalitas

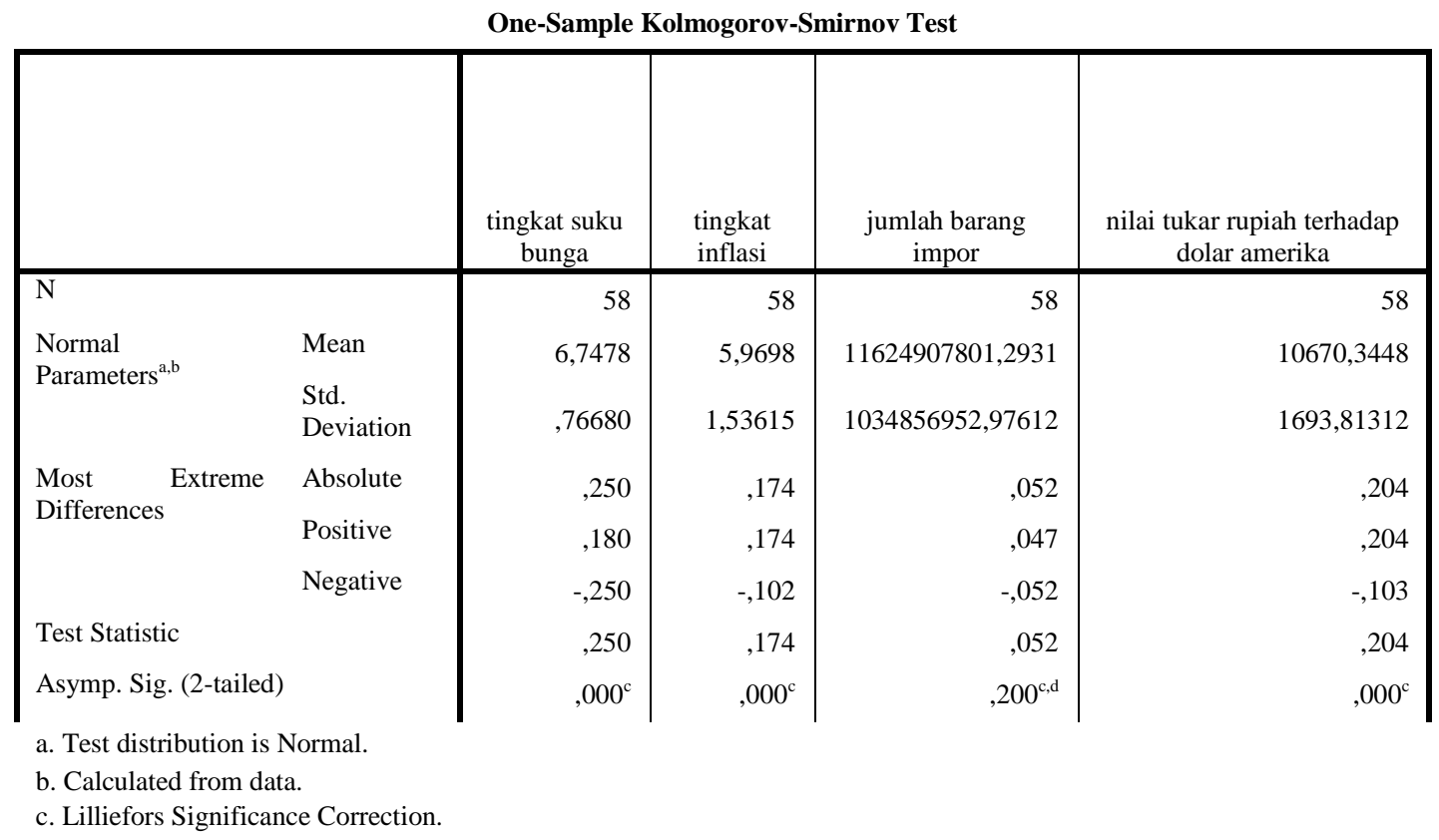

Hasil yang diperoleh menunjukan data pada tingkat suku bunga, inflasi dan nilai tukar rupiah terhadap dolar tidak berdistribusi normal dikarenakan nilai sig dibawah 0,05 , yang berdistribusi normal hanyalah jumlah barang impor saja, karena nilai signya lebih dari 0,05 yaitu sebesar 0,2. untuk itu analisis yang akan digunakan adalah analisis korelasi parsial menggunakan korelasi kendal dan uji regresi parsial menggunakan.

\section{Uji Hipotesis}

Berdasarkan dari uji persyaratan data di atas, karena uji persyaratan data tidak terpenuhi, maka uji hipotesis yang akan dipergunakan adalah uji hipotesis 
menggunakan korelasi kendaltau dan uji regresi sederhana menggunakan uji Theil.

\section{Uji Korelasi}

Pada uji hipotesis ini akan dilakukan secara parsial, yaitu mencari apakah terdapat hubungan positif antara tingkat suku bunga terhadap nilai tukar rupiah terhadap dolar Amerika. Terdapat hubungan positif antara tingkat inflasi terhadap dolar Amerika, terdapat hubungan positif antara jumlah barang impor terhadap nilai tukar rupiah terhadap dolar Amerika. Secara matematis, dapat dituliskan sebagai berikut:

\section{Hipotesis 1}

$H_{0}: \tau_{1}=0$ (Tidak terdapat hubungan antara tingkat suku bunga dengan nilai tukar rupiah terhadap dolar Amerika)

$H_{1}: \tau_{1} \neq 0 \quad$ (Terdapat hubungan antara tingkat suku bunga dengan nilai tukar rupiah terhadap dolar Amerika)

\section{Hipotesis 2}

$H_{0}: \tau_{2}=0$ (Tidak terdapat hubungan antara tingkat inflasi dengan nilai tukar rupiah terhadap dolar Amerika)

$H_{1}: \tau_{2} \neq 0 \quad$ (Terdapat hubungan antara tingkat inflasi dengan nilai tukar rupiah terhadap dolar Amerika)

\section{Hipotesis 3}

$H_{0}: \tau_{3}=0$ (Tidak terdapat hubungan antara jumlah barang impor dengan nilai tukar rupiah terhadap dolar Amerika)

$H_{1}: \tau_{3} \neq 0 \quad$ (Terdapat hubungan antara jumlah barang impor dengan nilai tukar rupiah terhadap dolar Amerika)

Berdasarkan hasil yang diperoleh, tingkat suku bunga, tingkat inflasi dan jumlah barang impor secara parsial memiliki hubungan dengan nilai tukar rupiah terhadap dolar Amerika.

\section{Uji Regresi sederhana}

Berdasarkan uji korelasi parsial yang diperoleh pada subbab sebelumnya, maka langkah selanjutnya adalah menguji hipotesis apakah setiap variabel memiliki pengaruh terhadapa nilai tukar rupiah terhadap dolar Amerika. Berikut adalah hipotesis yang akan diuji.

\section{Hipotesis 1}

$H_{0}: \beta_{1}=0 \quad$ (Tidak terdapat pengaruh antara tingkat suku bunga dengan nilai tukar rupiah terhadap dolar Amerika)

$H_{1}: \beta_{1} \neq 0 \quad$ (Terdapat pengaruh antara tingkat suku bunga dengan nilai tukar rupiah terhadap dolar Amerika) 


\section{Hipotesis 2}

$H_{0}: \beta_{2}=0$ (Tidak terdapat pengaruh antara tingkat inflasi dengan nilai tukar rupiah terhadap dolar Amerika)

$H_{1}: \beta_{2} \neq 0 \quad$ (Terdapat pengaruh antara tingkat inflasi dengan nilai tukar rupiah terhadap dolar Amerika)

\section{Hipotesis 3}

$H_{0}: \beta_{3}=0 \quad$ (Tidak terdapat pengaruh antara jumlah barang impor dengan nilai tukar rupiah terhadap dolar Amerika)

$H_{1}: \beta_{3} \neq 0 \quad$ (Terdapat pengaruh antara jumlah barang impor dengan nilai tukar rupiah terhadap dolar Amerika)

Uji regresi sederhana akan menggunakan uji theil, rumus yang akan digunakan adalah:

Dimana:

$$
z=\frac{\tau-\mu_{T}}{\sigma_{T}}
$$

$$
\mu_{T}=0
$$

$\tau$ adalah nilai koefisien korelasi kendal tau.

$$
\sigma_{T}=\sqrt{\frac{2(2 n+5)}{9 n(n-1)}}
$$

jika nilai $P(Z>z)<0,025$, maka tolak $H_{0}$ dan terima $H_{1}$. Berikut adalah urainnya.

\section{Hipotesis 1}

$z=\frac{0,471}{0,09}=5,22, P(Z>z)=0,000$, artinya terima $H_{1}$. Berdasarkan uji hipotesis maka dapat disimpulkan terdapat pengaruh antara tingkat suku bunga dengan nilai tukar rupiah terhadap dolar Amerika.

\section{Hipotesis 2}

$z=\frac{0,333}{0,09}=3,69, P(Z>z)=0,000$, artinya terima $H_{1}$. Berdasarkan uji hipotesis maka dapat disimpulkan terdapat pengaruh antara tingkat inflasi dengan nilai tukar rupiah terhadap dolar Amerika.

\section{Hipotesis 3}

$z=\frac{0,397}{0,09}=4,40, P(Z>z)=0,000$, artinya terima $H_{1}$. Berdasarkan uji hipotesis maka dapat disimpulkan terdapat pengaruh antara jumlah uang beredar dengan nilai tukar rupiah terhadap dolar Amerika. 


\section{Hasil Analisis Data}

Berdasarkan perhitungan di atas maka diperoleh kesimpulan bahwa terdapat hubungan dan pengaruh scara parsial antara tingkat suku bunga, tingkat inflasi dan jumlah barang impor dengan nilai tukar rupiah terhadap dolar Amerika.

Secara teori ekonomi makro yang dijelaskan olah Sukirno (2015) menyatakan bahwa suku bunga yang rendah cenderung akan menyebabkan modal dalam negeri mengalir keluar negeri. Apabila lebih banyak modal mengalir ke suatu negara, permintaan atas mata uangnya bertambah, maka nilai mata uang negara yang menjadi tujuan investasi akan meningkat dan nilai mata uang negara yang mengalirkan dana menjadi turun. Selain tingkat suku bunga, tingkat inflasi mempengaruhi juga nilai tukar rupiah terhadap dolar Amerika, dikarenakan inflasi menyebabkan harga-harga di dalam negeri lebih mahal dari harga di luar negeri, oleh sebab itu negara itu cenderung akan mengimpor barang-barang dan pada akhirnya nilai mata uang negara tersebut menjadi jatuh. Faktor terakhir adalah jumlah barang impor, semakin banyak barang impor yang masuk ke suatu negara, maka nilai mata uang negara tersebut akan turun, diakibatkan permintaan mata uang negara tersebut lebih sedikit dibandingkan permintaan negara pengimpor.

\section{E. SIMPULAN}

Berdasarkan perhitungan di atas maka diperoleh kesimpulan bahwa terdapat hubungan dan pengaruh scara parsial antara tingkat suku bunga, tingkat inflasi dan jumlah barang impor dengan nilai tukar rupiah terhadap dolar Amerika.

\section{DAFTAR PUSTAKA}

Kadir. (2015). Statistika Terapan. Jakarta: PT Raja Grafindo Persada

Kamus besar Bahasa Indoneisa. Edisi keempat. 2008. Jakarta: Gramedia Pustaka.

Mankiw, G. (2000). Teori Ekonomi Makro. Jakarta: PT Erlangga.

Rahardja,P. (2014). Teori Ekonomi Makro. Depok: Lembaga Penerbit Fakultas Ekonomi Universitas Indonesia.

Sukirno, S. (2014). Makroekonomi Teori Pengantar. Jakarta: PT Raja Grafindo Persada.

Suliyanto. (2011). Ekonometrika Terapan. Yogyakarta: PT Andi Yogyakarta.

Uki, Supardi, S. 2012. Aplikasi Statistika dalam penelitian. Jakarta: PT Ufuk Publishing House.

Zainul, Almasyah, A. (2015). Faktor-Faktor yang Mempengaruhi Kurs Rupiah terhadap Dolar Amerika Pasca Krisis (2000-2010). Jurnal Jibeka Vol. 9 Nomor 1 Februari 2015 hal 76-86. 